\title{
Customary Law Aspect on the Role of Religious Judge in the Case of Divorce
}

\author{
Nur Mohamad Kasim \\ nurkasim@ung.ac.id \\ Universitas Negeri Gorontalo, Gorontalo, Indonesia
}

\begin{abstract}
Background. Marriage is a formal tie between man and wife to establish a family. It is founded based on state and religious laws, thus it may cause legal events, such as divorce. This study aims at studying the role of a judge in inspecting the divorce case through the aspect of customary law in Gorontalo. Methods. The researcher uses a descriptive method of analysis with a sociolinguistic and legal anthropological approach to see the influence of grammar and development of Gorontalonese culture in utilizing religious judge to solve the divorce case. Results and discussion. This study shows that the judge can utilize cultural approach in the context of customary law to investigate divorce case, through either sociolinguistic interaction or interpersonal emotional ways. Both cultural approaches enable stakeholders to discuss household problems; thus, it made possible for involved parties to change their minds based on their interpersonal interaction with the judge
\end{abstract}

Keywords: Customary Law Aspect, Divorce, Religious Judge

\section{Introduction}

Indonesia is a legal state as the state aims at creating an orderly and prosperous state and community. The context of a legal state is grounded on Pancasila and the 1945 Constitution (hereinafter will be referred to as UUD 1945) as the highest source of law in this republic. UUD 1945 also serves as the unifier of its state and community, as Indonesia is the most culturally diverse nation.

Particularly, a community is arranged in the smallest social structure namely family, which consists of husband and wife. This smallest structure of the community is legally bounded by marriage. "Marriage is a formal tie between man and wife to establish a happy and eternal family, which is based on One Supreme God" [1].

The marriage bond is a relationship founded based on state and religious laws. Therefore, it may cause legal events, such as disintegration of the relationship between man and wife due to various factors. Factors, such as wife's disobedience toward the husband, or husband's violence or infidelity toward the wife, as well as other causes such as education, economic, ethics, moral, absence of harmony and responsibility can lead to disputes and can lead to divorce.

Ongoing disputes between husband and wife dominate the causes of divorce cases in Familial Courts in Gorontalo. Those cases often reach appeal and supreme courts.

The number of divorce cases is steadily increasing. Based on the data from 20132016, there are 2,575 divorce cases out reported at the Familial Court of Gorontalo 
(Pengadilan Agama Gorontalo, 2016). From this figure, it is known that the divorce cases increased by $50 \%$ annually.

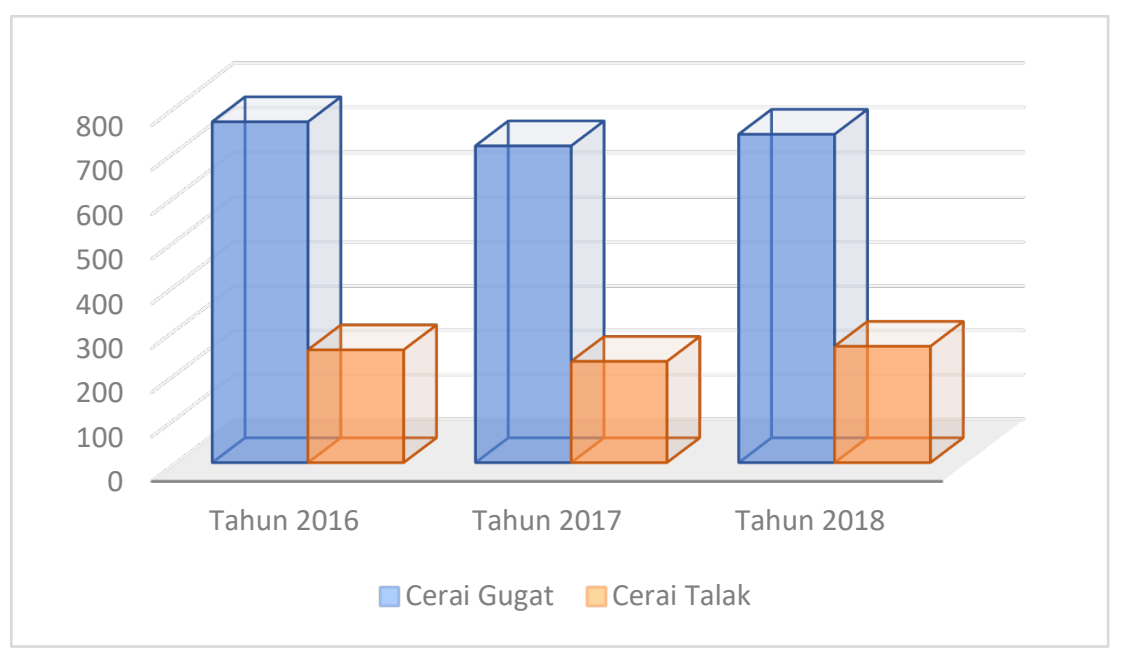

Fig. 1. Divorce Case Granted by The Familial Court of Gorontalo

Common awareness, especially in divorce cases, is needed. This is because the case has been bad precedence for familial courts in Indonesia. The familial court should be an institution that helps this nation to develop and able to professionally solve divorce cases. The professionalism of the institution not only lays on how they solve a marriage relationship but also on how they mediate a disputing husband and wife. This authority lays on the familial court judges.

Regardless to the fact that most of the solution for divorce cases in the familial court ends up with a divorce, it cannot undermine the judges' effort to make peace between the disputing parties as part of the case-solving mechanism. Therefore, a familial court judge in solving a divorce case is demanded to be credible and to possess the ability to solve cases peacefully without having to end a marriage relationship. A judge ability is not only on his or her professionalism but also in their ability to involve or make use of the local cultural aspect as an approach in solving a divorce case.

On this background, it is interesting to study the role of the judge in solving the divorce cases through Customary Law aspect in Gorontalo. In studying this aspect, the researcher uses a descriptive analysis method with sociolinguistic and legal anthropology approach to see the grammatical influence and cultural development of the Gorontalonese culture, which can be utilized by the familial court judge in solving the divorce case.

\section{Methods}

The researcher uses a descriptive method of analysis with a sociolinguistic and legal anthropological approach to see the influence of grammar and development of Gorontalonese culture in utilizing religious judge to solve the divorce case. 


\section{A Brief Study On Divorce}

Before deciding to divorce, both the husband and wife shall think deeply of what will happen subsequently [2]. Therefore, during marriage, when there is no either spiritual or physical compatibility between them to create a harmonious family, then the procedure of divorce may be proposed to the court [3].

Marriage law stipulates equal rights for either the husband or wife to propose divorce. KHI (Kompilasi Hukum Islam, Compilation of Islamic Laws in Indonesia) Article 14 mentions that disintegrated marriage due to divorce may be caused by talaq or based on procedure of divorce. Divorce due to talaq or procedure of divorce is only validated if conducted in front of the Religious Court hearing [4].

Divorce happens due to various factors. Below are some popular reasons for divorce. The complexity of problems in Indonesian society has added the dynamic of people's lives. As a result, life becomes more complex, and the burden of life and works have added to the stress level of people. These often become problems in marital lives as well.

In the modern era, every person is demanded to have not only a stable life but also to have a high level of socialization. These demands often become a problem in marital life. The most common problems in marital life are a financial problem. For instance, a working husband and wife have made it possible for the wife to have a larger income, and some of the financial burdens of that family has been the responsibility of the wife. As long as this is based on a common agreement, it should not be a problem. However, the husband often feels less dignified and does not want his role as the breadwinner for the family to be undermined by the wife. This can lead to problem or disputes that may lead to large disputes.

More complicated issue will appear when the husband is married with another woman within Islamic and customary legal traditions. It will deteriorate when the marriage ends up by having biological babies and when his divorce case from the previous marriage is judicially unfinished. More issues are about to rise then, when the wife from the second marriage (marrying within Islamic and customary legal traditions) divorces her sirri husband. She will unable to demand his responsibility and resolve it legally as only Islamic and customary legal marriage is considered a valid marriage. Moreover according to the Marriage Law Number 1 of 1974, invalid marriage will not be formally and judicially admitted [5].

Hurlock argues divorce constitutes a culmination of bad marriage customization. It occurs at the time the husband and wife cannot find any solution they cannot be satisfied with. The Law of the Republic of Indonesia Number 1 of 1994 Article 16 mentions divorce may happen when the interested husband and wife are impossibly united in a household. Meanwhile Article 18 mentions divorce is effective when the court has condemned it. Prior to the condemnation, the court will find attempts to unite the people, so divorce will take place when there is no attempt successful [6].

The second problem is marital adaptation. In this case, it is related to Indonesian culture that marital life often involves the husband and wife families. Some of the examples are the demand to have children or minimum frequency to visit family; these can trigger disputes that can endanger marriage. The third problem is that a husband or wife becomes too busy.

Divorce is the end of a marriage. Disputes often associate with unhappiness, spouse infidelity, or other problems in marriage; this may lead to a decision to divorce. Married couples often consider divorce as the final solution. Another reason for divorce is to teach spouse a lesson as a way out to end the misery in marriage. However, divorce is not always 
solved problems in a marriage; some problems may still exist after divorce. Below are several major causes of divorce:

1. Communication failure

Incompatibility due to communication failure between husband and wife often becomes the trigger for divorce. Lack of communication leads to lack of trust, understanding, and disputes. This will ultimately lead to divorce when both parties are unwilling or fail to make communication.

2. Infidelity

Another main cause of divorce is spouse infidelity. The one being cheated on will feel hurt and unable to forgive and choose divorce as a solution. Sometimes, the cheating spouse often chooses to divorce his or her spouse for the new beau.

3. Domestic Violence

Divorce due to domestic violence is also prominent. Many choose to save their lives through divorce rather than facing lifetime torture through marriage, either physically or mentally.

4. Economic Problems

There are also divorce cases due to economic problems. Spouse is considered unable to fulfill the family needs. Hence, the spouse filed for divorce.

5. Early marriage

Too young to get married made many young couples not ready to face various marriage challenges. Hence, divorce is considered a decision when facing a problem in a marriage.

6. Cultural changes

Divorce was considered taboo. However, it has become a trend and even a lifestyle. Many spouses considered inconceivable disputes as a reason for a divorce. They rather decide to get divorced than saving their marriage.

as follows [1]:

The reasons for divorce as mentioned in Article 39 (2) or Law No. 1 of 1974 EW are

1. One of the spouses, either husband or wife, commits adultery, a heavy drinker, a drug user, a gambler, and other things. Hence, it is hard to rehabilitate.

2. One of the spouses leaves his or her spouse for two consecutive years without any permit and without any legal reasons, or due to other things outside of his or her control.

3. One of the spouses is sentenced with five years of a prisoning sentence or other heavier sentence.

4. One of the spouses commits violence that endangers the spouse or another party.

5. One of the spouses is injured or become invalid or contract a disease that made him or her unable to carry out his or her function as husband and wife.

6. Constant disputes between husband and wife with no chances for reconciliation in marital life.

Compilation of Islamic Law (hereinafter will be referred to as KHI) in Article 116 has been explaining in detail several reasons as a basis for filing a divorce by adding two specific reasons as follow [7]:

1. One of the spouses, either husband or wife, commits adultery, a heavy drinker, a drug user, a gambler, and other things. Hence, it is hard to rehabilitate.

2. One of the spouses leaves his or her spouse for two consecutive years without any permit and without any legal reasons, or due to other things outside of his or her control. 
3. One of the spouses is sentenced with five years of a prisoning sentence or other heavier sentence.

4. One of the spouses commits violence that endangers the spouse or another party.

5. One of the spouses is injured or become invalid or contract a disease that made him or her unable to carry out his or her function as husband and wife.

6. Constant disputes between husband and wife with no chances for reconciliation in marital life.

7. The husband violates the taklik talak (reasons for a talaq/divorce to happen).

8. Change of belief or denouncing Islam which made there is no peace in the household. According to aforementioned causes, divorce is also potential to happen due to a classical reason, and hence enables the interested party to minimalize it. Divorce is not something new for us, as we know that a lot of celebrities and other people had divorced their partner. The great number is surprising when there are many effective solutions or methods offered to prevent divorce. Unfortunately, along with the world development, the number of divorces keeps increasing.

\section{Divorce Case Checking By Judge}

Legal existence is supported by the judge existence as the legal enforcer. The law and judge are strongly connected to and complement each other. Mr. R. Tresna argues, "When there is the law, there is the judge." It impacts on the Islamic law and judge, issuing an adage clarifying that "when there is the Islamic law, there is the Islamic judge". Today, apparently when there are Moslems, there is the Islamic law and judge. In Indonesia, the Islamic judge is embodied by the religious court, as confirmed by the Article 24 Paragraph (2) the 1945 Constitution. By this authority, the judge is able to investigate the issue for the sake of Justice by the Almighty God [8].

Based on Law No. 3 of 2006 [9], Familial court is obliged and authorized to investigate, make a decision, and solve cases on the first level between those who are Islamic believers in the case of (Article 49):

1. Marriage;

2. Inheritance;

3. Deed;

4. Grant;

5. Wakaf;

6. Zakat;

7. Infaq;

8. Shadaqah; and

9. Sharia economy.

The religious court will make attempts to unite both parties to return their harmonious life as a husband and wife. They will be given several days to ponder their decision over the divorce. When there is no agreement met, the court will condemn them to divorce [10]. Further, the judge is the familial court judge or religious court judge and appeal religious or familial court judge and/or officer that implement the judicative authority (Article 11). The familial/religious judge authority is directly under the authority of judicial authority of Religious/Familial Court either in district/city level or in provincial level. 
In Article 13 of Law No. 3 of 2006 [9], it is mentioned that to be appointed as a judge in the religious/familial court, a person should meet the following requirements:

1. Indonesian Citizen;

2. Islam;

3. Pious toward the One Supreme God;

4. Loyal to Pancasila and UUD 1945;

5. Holds a degree in Sharia and/or Bachelor of Law and master Islamic law;

6. Mentally and physically healthy;

7. Has dignity, honest, fair, and of good morals and behaviors; and

8. Was not associated in a prohibited organization, the Indonesian Communist Party and its underwings, or not a person who directly involved in the $30^{\text {th }}$ September movement which was organized by the Indonesian Communist Party.

Meanwhile, the judicial authority in adjudicating a divorce case based on Familial/Religious Court Law is described as follow:

1. The judge investigates/checks the divorce case in no later than 30 days after the case is filed to the court;

2. The judge investigates the case by listening to both plaintiff and defendant, then the witnesses;

3. The judge investigates the divorce case by trying to reconcile the husband and wife. When the reconciliation is reached, then the divorce case is discontinued and cannot be refiled in a new lawsuit using a similar reason. Whereas, when reconciliation is not reached, then the lawsuit is continued;

4. The judge continued the lawsuit investigation in a close manner related to the postdivorce rights and obligation of the husband and wife;

5. The judge adjudicates/decides the case.

The effort for reconciliation or mediation mechanism needs to be emphasized before the case is decided. The judge panel is obliged to advise the plaintiff or the defendant (husband and wife) during the court hearing. The judges try at their best to provide advice or best solutions to the plaintiff or defendant, and when judges could not find the best solution, then actions according to the court procedure can be taken.

Before deciding a case, judges need to carry out a deliberation with the plaintiff or defendant in the court hearing, when the deliberation has been carried out, but one of the party disagrees with the decision of the chief judge, then the judges advise or provide knowledge toward the disagreeing or dissatisfied party on the first level court hearing. The judge panel can ask the dissatisfied party to go for appeal level [11].

When a regulation is substantially unclear and ambiguous, hence different interpretations, in practical level, it will impact on different application levels. Perma Number 1 of 2008 also contains some interpretable articles; such as articles to comprehend duty for arranging mediation. Here, there are two different mindsets: firstly, mediation process shall be conducted in the level of civil dispute resolution proposed to the court and secondly, mediation shall be conducted in the level of civil dispute resolution proposed to the court when both parties are present in the court. Regardless their correctness or incorrectness, one of those understanding will give different practical implications [12].

Mediation procedure by a judge in a divorce case is a crucial procedure; this check becomes the most important benchmark to determine the future of a marriage relationship between the plaintiff and the defendant. The active role of the judge in mediation is not only carried out ex officio by providing advice or knowledge, but judges can also involve family, friends or other figures or agencies, which considered important to assist in the effort to reach 
reconciliation between husband and wife. These efforts are as stipulated in Article 31 (2) of Government Regulation No. 9 of 1975 on Implementation of Marital Law [13].

\section{Cultural Approach As An Effort For The Judge In Divorce Case In Gorontalo}

The Law of the Republic of Indonesia and the Indonesian legislation take a great concern of local wisdom, because together with the Indonesian positive law, it constitutes one of the elements for the judge consideration to make decision. Why? Local wisdom contains policies made by the local people. They generated traditions philosophically containing moral values upheld by them.

In facing legal issues, every judge shall look up to the local wisdom, since people regards the wisdom as absolute justice. Furthermore, the local wisdom is crucial because [8]:

1. Local wisdom shall be prioritized as the legal source when the judge cannot find any written legal source as a positive law.

2. Local wisdom may be accompanied by the written law acting as a complementary law and helping the judge make a decision on a suit.

3. Local wisdom can also be the legal source as long as it does not contradict the supreme legal principle.

In checking a divorce case, divorce is not always the result. The judge can decide to reconcile the disputing parties. The initial step in the divorce case checking by the judge is by asking questions to the plaintiff or the defendant. The questions are usually detailed questions and demanding questions. These questions are to ensure the description of the parties and the witnesses are of no doubts in going through the trial process. Clear testimonies are important to ensure the judges as their basis for deciding a case. Therefore, the judge often repeats testimonies provided by parties or witnesses.

\subsection{Cultural approach through sociolinguistics aspect}

Considering the way the judges check the case above, it becomes important to study the language of a judge as an approach within the process of checking a case. Language influences changes in a person's state of mind. For instance, when a person is under stress, it is possible for that person to think unclearly. Thus, often the way she or he communicates with others uncomfortably or even his/her communication may result in conflict. In this case, a familial/religious court judge is demanded to have good moral and integrity in his/her daily interaction, and more importantly within the process of adjudicating or checking a divorce case. It means that a judge should be considered as an advisor, who can provide advice or knowledge patiently and wisely.

In his book titled "How to Do Things with Words", J.L Austin (1962) conveys that functions formed by utterances are parts of interpersonal communication expressed in a sentence. He adds that language is not only used as the message transmitter, but also an act creator consisting of two categories, i.e. performative sentence and constative sentence. The first sentence can be defined as an expression of: (1) When the judge declares, "Before you give any information, I shall take your oath," (2) When the defendant says, "I apologize, Sir," and (3) When the judge states, "I close the trial today" [14]. 
The expressions indicate that during the trial, the judge has applied the rule of using language correctly, and thus to make them more understandable. Good and polite speech is uttered by not only academicians (lecturers) to their students, teachers to their students, doctors to their patients, lawyers to their clients, but also judges to witnesses or defendants in courts. Court is a place to decide a case for all justice seekers. During the court process, the judge, attorney, defendant, and witness communicate by language. The use of polite, assertive, good, and correct language is the beginning of good, legal communication to manifest justice.

In the Religious Court in Gorontalo, many judges adjudicate cases using daily local language. This is due to the majority of disputing parties are Gorontalonese people who have difficulties speaking proper and correct Indonesian language. Therefore, it is appropriate for a judge in checking a divorce case to use the cultural approach from the sociolinguistic aspect.

Regarding the use of polite language in a court, we present an example in Gorontalo language. Here is the excerpt, directly taken from the trial of divorce issue.

$\begin{array}{ll}\text { Chief Judge } & \text { : (Hari ini bawa saksi?) Do you bring any witness today? } \\ \text { Plaintiff (woman) } & \text { : (Saksi yang kemarin so tidak mau pak) The last witness will }\end{array}$ not come, Sir.

Chief Judge : (Bukan saksi yang kemarin, so orang lain poli? ) It is not $\mathrm{him} /$ her, so you bring another one?

Plaintiff : (Cuma orang lain yang mau soalnya saksi yang lalu...) Only other people are willing to. The last witness ....

Chief Judge : : (Kenapa) Why?

Plaintiff

: (Dia tarik-tarik di jilbab itu ti...) Someone pulled her veil.

Chief Judge

Plaintiff

Chief Judge

: (Ti tante itu yang dari...) The one that was ....

: (Ya)Yes.

: (Dari apa itu...) Why?

Plaintiff

Chief Judge

Plaintiff

: (Depe tante itu ) That was her aunt.

: (Aaa) Oh, I see.

: (Jadi kalo bakudapa deng saya dia so tida mau) She refuses to meet me now.

Chief Judge : : (Tidak boleh bagitu, bagimana kong babuju pa maitua kong bagitu. Babuju, buju bae-bae. Jangan datang datang.... Saya juga kalo dibuju bagitu saya tetap tida mau. Buju itu bae-bae. Cuma babuju ta'u... (Diskusi dengan kedua hakim anggota) Saudara, kira-kira apa yang mau disampaikan?) No, she must not. How do you persuade your wife, then? You have to persuade people gently. If you persuaded me by that way, I would not like to grant your wish too. You shall do that well. It is only the matter of persuading. (Discussing with two member judges) Do you want to propose something?

Plaintiff : (Apa itu pak?) What is it, Sir?

Chief Judge : (Untuk meyakinkan saksi bahwa yang itu adalah butul-butul begitu selain saksi itu kan otomatis harus cari yang lain, ini mau disumpah kek, mau di apa kek) To make the witness believe your seriousness. If the last one does not come, we have to automatically look for another one. I would like her to take an oath.

Plaintiff : (Tunda..) Could we postpone this trial?

Chief Judge : (Ha..? Bersumpah?) What? Taking the oath? 


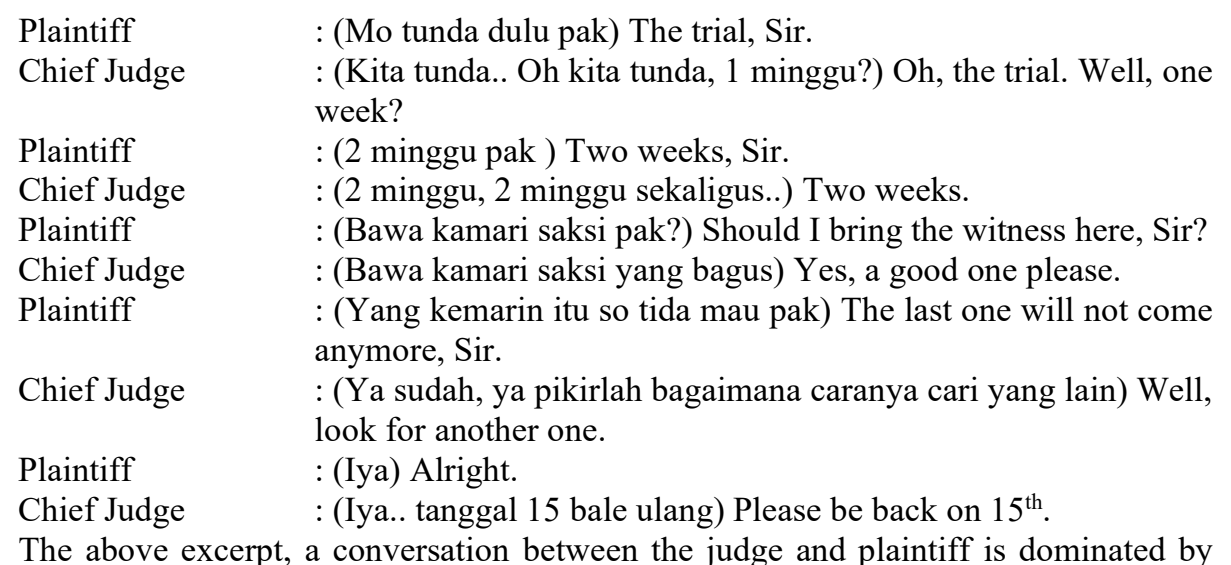

Gorontalo language. Both speakers tried to understand what the other was trying to communicate. The use of polite, assertive, good, and correct and well behaving in a trial is regulated by the code of conduct in Paragraph 13b the Law of the Republic of Indonesia Number 49 Year 2009 on General Court. The regulation explains that judge shall do their duties professionally [15].

Language in a community serves to control social interaction. This statement is based on the fact of the shift of community structure due to the influence of a language. In Gorontalo, for instance, the local language is mostly used by the elders for daily conversation; but it is different when it comes to the younger people. There is a gap between those who use Gorontalo language and the group of young people who use Gorontalo language mixed with the Sulawesi dialect. The former will feel more civilized as their Gorontalo language is dominated by polite language.

Therefore, judges who adjudicate divorce cases in Gorontalo religious court should use the cultural approach from this sociolinguistic aspect in adjudicating divorce case as it has several benefits as follow:

a) The judge can adapt to the party that he/she is currently checking by using similar language. If Gorontalo language is used, the judge can ask a question in Gorontalo language to indirectly create an emotional bond between the judge and the party being investigated.

b) This developed emotional bond will ease the judge in digging information and finding the intention of the parties based their answers.

c) Cultural approach through this sociolinguistic aspect will ease the parties to provide their testimonies without feeling any pressure. Thus, the trial process will put disputing parties in a comfortable position. Thus, they can think clearly.

\subsection{Judge processional approach through customary law}

Such kind of approach can also be applied in the mediation stage or to reconcile. The cultural approach of the judge can be applied not only in ex officio manner; rather, it can also be applied by the judge as rechtvinder or an inventor of a new law for the purpose of common just among the parties. For this purpose, the judge can position himself/herself as a figure who understand religion and/or cultural elder who has knowledge on customary law about marriage. 
In Gorontalo customary law, an elder is a man who knows the value of the local wisdom and the custom to be preserved. A cultural leader has the ability to provide advice for the community in upholding the values of the local wisdom for a better and orderly life.

The ability mentioned above is important to be mastered by a religious court judge. It is important that the effort to reconcile the disputing parties is not only providing legal understanding toward the disputing parties but also moral enhancement by providing the values of their own culture, and religious values toward the plaintiff and the defendant in order for them to be aware and try to preserve their marriage.

\section{The Existence Of Customary Law To Influence Judge Role In Divorce Case}

Customary law is a law growing and developing among the society. It represents national aim and cultural common sense. Hence the law is also referred to unwritten law with acceptable implications for all Indonesian citizens. Ter Haar argues that customary law constitutes all regulations applied in firm decisions and binding realization [16]. The argument is known as decision theory (beslissingenleer). Therefore customary law is realized and maintained by decisions of legal community. Furthermore legal functionary decisions cover legal functionary decisions stipulated by the judge, male village elder, village meeting, land representatives, and other village staffs.

Today legal configuration had been transformed and customary law is an organic part of the state law. The realization is stipulated in the Law Number 4 of 2004 on Power, Judge regulated in Article 24 Paragraph (1) stating that all court decisions shall contain not only logic and fundamental of the decision, but also a certain article of interested legislations or written legal sources as a base to adjudicate. The Article is strengthened by Article 28 stating that the judge shall dig, follow, and understand legal values and justice living among communities.

Based on those two articles, customary law can be a base for the judge to adjudicate and to write decision in the court because the written law source intended in Article 25 Paragraph (1) is customary law. Moreover legal values and people's sense of justice are also manifested in customary law under an assumption that customary law is the law growing and developing in the society. Both articles authorize the judge to write decisions by referring to customary law [16]

In relation to the role of the judge in adjudicating a divorce case through a cultural approach, it is actually outside the above mechanism as stipulated by the Perma No. 1 of 2016 (Anonim, 2016). However, the divorce case is not merely a personal case, the bad impact of divorce needs to be minimized as it will leave a scar for life, especially for children that may exist within this broken marriage.

According to the above discussion, husband and wife relationship is the smallest structure of a community. A good marital relationship will ensure that interpersonal relationship within the community will be healthier and conflicts can be averted. Therefore, the role of religious court judge in adjudicating divorce case is expected to have more than just adjudicating the case. Judges should become those who mind the cultural values based on the customary law: 
$\checkmark$ The ability of the religious court judge to position himself/herself as a person who understand religion and cultural values, which is a reflection of his/herself as mentioned in Article 12B (1) of Religious Court Law that

"Hakim harus memiliki integritas dan kepribadian tidak tercela, jujur, adil, profesional, bertakwa, dan berakhlak mulia, serta berpengalaman di bidang hukum/judge should have integrity and good moral, attitude of honesty, just, professional, pious, and experienced in law".

In practice, a judge even can be considered as a Hakam, a trusted person to become a reference for two parties to freely share their feelings and thoughts, where parties that would like to divorce can tell their marriage problems from all aspects of life.

One of the Islamic teachings proposes, "al-Aadatu Muhkamatu", or "Customs and tradition may be regarded the law." Judges from either religious or other environments shall pay attention the fact for the sake of justice (Arto, 2018).

The practice of a judge in adjudicating a divorce case is custom within the community that can be implemented before a case is filed to the court. The position of a judge is as a neutral party, who try to bring back peace into the household through deliberation and agreement.

In the litigation process, the role of a judge can be replaced by judge or judge can position himself/herself as a judge, considering that one of the most important obligations of the judge in a divorce case is to reconcile the disputing parties and avert a divorce. The judge before adjudicating a divorce case should become a mediator and considered as an elder within a community structure but within the court context.

\section{Conclusion}

The role of a religious court judge is important in adjudicating a divorce case. This is because judges have their professional ethics as well as a trusted person in reconciling the disputing husband and wife.

The role of the judge in adjudicating divorce case can use cultural approach through customary law, either through sociolinguistic interaction or through interpersonal emotional ways. Both cultural approaches provide ways for the parties to discuss their marriage problems. Hence, it made possible for the disputing parties to change their pattern of thinking based on their own opinion and due to their interpersonal interaction with the judge.

\section{References}

[1] Anonim, Undang-undang Nomor 1 Tahun 1974 tentang Perkawinan, Jakarta, 1974.

[2] N. M. Kasim, "Problem Perceraian dalam Tinjauan Sosiolinguistik dan Hukum Islam: Studi Kasus di Pengadilan Agama Gorontalo," Gorontalo, 2012.

[3] S. Sarwono, Psikologi Remaja, Edisi 15 penyunt., Jakarta: Rajawali Pers, 2012.

[4] M. Syarifuddin dan S. Turatmiyah, "Perlindungan Hukum Terhadap Perempuan dalam Proses Gugat Cerai (Khulu') di Pengadilan Agama Palembang," Jurnal Dinamika Hukum, vol. 2, no. 2, 2012 . 
[5] R. S. Siregar, "Dampak Perceraian yang Tidak Sesuai Dengan Prosedur Perundang-undangan," FITRAH, vol. 01, no. 01, 2015.

[6] R. Y. Widiastuti, "Dampak Perceraian Pada Perkembangan Sosial dan Emosional Anak Usia 56 Tahun," Jurnal PG. PAUD Trunojoyo, vol. 2, no. 2, 2015.

[7] H. Muslida, S. Tency, I. Emi dan A. Pelu, "Kekerasan Seksual dan Perceraian," Malang, 2009.

[8] M. Arto, Penemuan Hukum Islam Demi Mewujudkan Keadilan Penerapan Penemuan Hukum, Ultra Petita, \& Ex Officio Hakim Secara Proporsional, Yogyakarta: Pustaka Pelajar, 2018.

[9] Anonim, Undang-undang Nomor 3 Tahun 2006 tentang Peradilan Agama, Jakarta, 2006.

[10] B. Nasir, "Faktor-faktor yang Mempengaruhi Perceraian di Kecamatan Sungai Kunjang Kota Samarinda," Jurnal Psikostudia Universitas Mulawarman, vol. 1, no. 1, 2012.

[11] Asriani dan L. Ilham, "Peranan Hakim Dalam Menyelesaikan Perkara Perceraian di Pengadilan Agama Kabupaten Pangkep," Tomalebbi, vol. 2, no. 2, pp. 24-28, 2015.

[12] T. Sofiani, "Efektivitas Mediasi Perkara Perceraian Pasca Perma Nomor 1 Tahun 2008 di Pengadilan Agama," Jurnal Penelitian, vol. 7, no. 2, 2010.

[13] Anonim, Peraturan Pemerintah Nomor 9 Tahun 1975 tentang Pelaksanaan Undang-undang Perkawinan, Jakarta, 1975.

[14] S. Purnama, "Tindak Tutur Hakim Berdasarkan Undang-undang RI Nomor 49 Tahun 2009 tentang Peradilan Umum," Sosio e-Kons, vol. 7, no. 2, 2015.

[15] Anonim, Undang-undang Nomor 49 Tahun 2009 tentang Perubahan Kedua Atas Undangundang Nomor 7 Tahun 1989 tentang Peradilan Agama, Jakarta, 2009.

[16] E. Susylawati, "Eksistensi Hukum Adat dalam Sistem Hukum Indonesia," Al-Ihka, vol. IV, no. $1,2009$. 